\title{
A proteomic analysis of Curcuma comosa Roxb. rhizomes
}

\author{
Apaporn Boonmee ${ }^{1}$, Chantragan Srisomsap ${ }^{2}$, Daranee Chokchaichamnankit ${ }^{2}$, Aphichart Karnchanatat ${ }^{3}$ and \\ Polkit Sangvanich ${ }^{1 *}$
}

\begin{abstract}
Background: The similarly in plant physiology and the difficulty of plant classification, in some medicinal plant species, especially plants of the Zingiberaceae family, are a major problem for pharmacologists, leading to mistaken use. To overcome this problem, the proteomic base method was used to study protein profiles of the plant model, Curcuma comosa Roxb., which is a member of the Zingiberaceae and has been used in traditional Thai medicine as an anti-inflammatory agent for the treatment of postpartum uterine bleeding.

Results: Due to the complexity of protein extraction from this plant, microscale solution-phase isoelectric focusing (MicroSol-IEF) was used to enrich and improve the separation of Curcuma comosa rhizomes phenol-soluble proteins, prior to resolving and analyzing by two-dimensional polyacrylamide gel electrophoresis and identification by tandem mass spectrometry. The protein patterns showed a high abundance of protein spots in the acidic range, including three lectin proteins. The metabolic and defense enzymes, such as superoxide dismutase (SOD) and ascorbate peroxidase, that are associated with antioxidant activity, were mainly found in the basic region. Furthermore, cysteine protease was found in this plant, as had been previously reported in other Zingiberaceae plants.

Conclusion: This report presents the protein profiles of the ginger plant, Curcuma comosa. Several interesting proteins were identified in this plant that may be used as a protein marker and aid in identifying plants of the Zingiberaceae family.
\end{abstract}

Keywords: Curcuma comosa Roxb, Proteomic, MicroSol-IEF, Zoom-IEF, Lectin, Superoxide dismutase

\section{Background}

Plants in Zingiberaceae family are widely distributed in many countries of Southeast Asia. In Thailand at least two-hundred species of Zingiberaceous plants are found and these include members of various genera, such as Alpinia, Amomum, Curcuma, Etlingera, Kaempferia, and Zingiber [1]. Zingiberaceous plants have been widely used in traditional medicine, as well as a food flavoring and spice agents. Many studies have focused on the bioactive small organic compounds from these plants and have supported the traditional medicinal use of the plant extracts, such as curcumin [2], sesquiterpene [3-5], and various essential oils [6-8], flavonoids and phenolic compounds

\footnotetext{
* Correspondence: polkit@gmail.com

'Department of Chemistry, Faculty of Science, Chulalongkorn University, Bangkok, 10330, Thailand

Full list of author information is available at the end of the article
}

[9,10]. In addition, the biologically active proteins reported from Zingiberaceae plants include, antifungal proteins from Zingiber officinalis [11] and antioxidant proteins from C. longa [12] and C. zedoaria [13]. Interestingly, the lectins were also found in many species of this Zingiberaceous plants. The lectins or agglutinin proteins, a class of carbohydrate-binding non-immune origin proteins, have been used as tools in analytical biochemistry [14,15] including in medical applications, such as drug delivery [16], blood typing [17] and potential antineoplastic drugs [18], amongst others. Their actual physiological functions are likely to be in the defense against phytophagous predators (mostly insects) and phytopathogenic microorganisms $[19,20]$. These plant lectins have been found in a variety of plant species, including the ginger family where, for example, the mannose-binding lectin cDNA, $Z$. officinale agglutinin (ZOA) [21], was cloned from the rhizomes of $Z$.
C Biomed Central

() 2011 Boonmee et al; licensee BioMed Central Ltd. This is an Open Access article distributed under the terms of the Creative Commons Attribution License (http://creativecommons.org/licenses/by/2.0), which permits unrestricted use, distribution, and reproduction in any medium, provided the original work is properly cited. 
officinale. According to the similarity of DNA sequences between ZOA and two other lectins, that is Galanthus nivalis agglutinin (GNA) from the snowdrop, which is highly toxic to sap-sucking insects, and Gastrodia elata antifungal protein (GEAFP), belonging to Orchidaceae lectins, ZOA may have defense based activities along the same lines as these two proteins. Heamagglutination activity was previously determined to be present in fifteen Curcuma plant species when assaying the crude rhizomal protein extract against rabbit erythrocytes [22], and this array of lectin-like activity positive plants included $C$. xanthorhiza, which is closely related to C. comosa. Certainly, purified lectins have been reported in a few Zingiberaceae plants. A $32.4 \mathrm{kDa}$ lectin enriched from $C$. amarissima Roscoe [23] revealed a growth-inhibitory activity against three plant pathogenic fungi (Fusarium oxysporum, Exserohilum turicicum and Colectrotrichum cassicola), and showed in vitro cytotoxicity against the BT474 breast cancer cell line. A thermostable lectin of $41.7 \mathrm{kDa}$ isolated from Kaempferia parviflora [24] showed heamagglutination activity against several different erythrocyte sources, with the strongest activity observed against rabbit red blood cells.

However, most plants in this family have very similar botanical characteristics and this makes it very difficult to clearly identify each species. The mistaken identification of medicinal plant materials is a serious problem for both manufacturers of traditional medicine products and researchers. There are a few methods to distinguish each species of plant, such as botanical characteristics by specialized taxonomists or DNA sequence based methods (e. g. establishing molecular operational taxonomic units with conversion to species by sequence identity to known species in the NCBI database). However, although the latter method is tissue and developmental stage independent, it is time consuming and complicated (due to the problem of discrimination of variety/cultivar polymorphism versus cryptic or sibling species).

Recently, proteomic tools have been used to identify types or isolates in many organisms [25-27] so this technique may be the one of the choices for the classification of Zingiberaceous plants. Of course, with no current baseline database it is far from clear how much the proteome for a specific tissue (e.g. rhizome) may vary within a species due to local genetics (cultivars) or cultivation conditions compared to between species, and so how useful this approach could be, but nevertheless under such a scenario it could still be used for following specific cultivars/cultivation conditions for quality control checking of any given cultivar. Thus, the aim of this report was to perform a preliminary study of the phenol-soluble protein profile from C. comosa as an initial model plant from the Zingiberaceae family.
Because in traditional Thai medicine, the rhizome is generally the part of the plant that is most wildly use and because a higher amount of protein is present in rhizome than in other parts, the protein database study in bulbous plants and those from Curcuma are usually used the rhizomes, respectively. For this reason, we selected $C$. comosa, an herb with large rhizome, as the model Zingiberaceae plant for proteomic study. C. comosa, commonly known as Waan Chak Mod Look in Thai, has been used as a traditional medicine for the treatment of postpartum uterine inflammation, perimenopausal bleeding and hemorrhoids. The isolated compounds from this plant have been reported to display various biological properties, such as estrogenic [28], anti-inflammatory [29], choloretic [30], antioxidant [31] and nematocidal [32] activities. However, the protein profile from this plant has not been reported. Therefore, the proteomic analysis of the rhizomes of C. comosa is expected to be useful for both establishing the potential of protein fingerprints in Zingiberaceae family and for the investigation of its specific proteins in a high throughput manner.

\section{Methods}

\section{Protein extraction}

Fresh rhizomes of C. comosa purchased from a local market in Bangkok, Thailand. A voucher specimen (BKF. No. 97298) is deposited at The Forest Herbarium (BKF), Royal Forest Department, Bangkok, Thailand. Grind fresh tissue of this plant to a powder with liquid nitrogen in a mortar and pestle. Base on C. longa proteomic [33], there are some interference compounds need to remove. Therefore the use of selection extraction method and buffer for C. comosa was similar with C. longa with slightly modification. Briefly, the plant powder $(5 \mathrm{~g}$ ) was extracted by suspension in $20 \mathrm{~mL}$ of extraction buffer $(0.5 \mathrm{M}$ Tris, $30 \mathrm{mM} \mathrm{HCl}, 0.1 \mathrm{M} \mathrm{KCl}$, $0.7 \mathrm{M}$ sucrose and $1 \%(\mathrm{v} / \mathrm{v}) \beta$-mercaptoethanol) for 30 $\min$ at $4^{\circ} \mathrm{C}$, whereupon the supernatant was then collected by centrifugation at $4,000 \times \mathrm{g}$ for $10 \mathrm{~min}$. The precipitate was extracted twice in extraction buffer and the poled extracts were then extracted with a 1:5 (v/v) ratio of water-saturated phenol at $4^{\circ} \mathrm{C}$ for $60 \mathrm{~min}$. After phase separation the phenol phase was then harvested and proteins were precipitated from the phenol phase by the addition of a four-volume of $0.1 \mathrm{M}$ ammonium acetate in methanol and left overnight at $-20^{\circ} \mathrm{C}$. The resulting phenol-soluble protein pellet was collected by centrifugation at 4,000 $\times \mathrm{g}$ for $10 \mathrm{~min}$, resuspended in cold water with sonication for $3 \mathrm{~min}$ and then precipitated again in nine volumes of cold acetone at $-20^{\circ} \mathrm{C}$ for $2 \mathrm{~h}$ and centrifuged at $4,000 \times \mathrm{g}$ for $10 \mathrm{~min}$. The protein pellet was air-dried to remove the acetone. The amount of protein in each sample was determined by the Bradford assay [34]. 
Microscale solution-phase isoelectric focusing (MicroSolIEF) of the protein extract

Aliquot protein $(3 \mathrm{mg})$ from the isolated proteins (115.5 $\mathrm{mg}$ ) were dissolved in $0.2 \mathrm{~mL}$ of solubilization buffer $(7.7$ $\mathrm{M}$ urea, 2.2 $\mathrm{M}$ thiourea and 4.4\% (w/v) CHAPS) and then $20 \mu \mathrm{l}$ of $100 \mathrm{mM}$ iodoacetamide (IAA) was added, mixed and incubated in the dark for $30 \mathrm{~min}$ at room temperature. After this incubation, the proteins were then precipitated by the addition of four volumes of cold acetone and harvested by centrifugation, as described above. The protein pellet was resuspended in solubilization buffer and supplemented with $10 \mathrm{mM}$ dithiothreitol (DTT), $0.8 \%$ (w/ v) ampholine and trace amount of bromophenol blue (The final concentration of protein was approximate $1.5 \mathrm{mg} /$ $\mathrm{mL}$ ). The Zoom-IEF fractionator (Invitrogen, Carlsbad, CA, USA) was assembled with three disks ( $\mathrm{pH} 3.0, \mathrm{pH} 5.4$ and $\mathrm{pH} 10.0)$. The protein solution $(0.65 \mathrm{~mL})$ was loaded between disk $\mathrm{pH} 3.0-5.4$ and $\mathrm{pH}$ 5.4-10.0 and focused at $100 \mathrm{~V}$ for $20 \mathrm{~min}$, followed by $200 \mathrm{~V}$ for $80 \mathrm{~min}$ and finally $600 \mathrm{~V}$ for $80 \mathrm{~min}$. After separation by Zoom-IEF, the protein solution was kept at $4^{\circ} \mathrm{C}$ for further analysis.

\section{Two-dimensional polyacrylamide gel electrophoresis (2- DE)}

The protein samples $(200 \mu \mathrm{g})$ were loaded onto immobilized pH gradient (IPG) gel strips (GE Healthcare, Biosciences, Uppsala, Sweden) and left overnight at room temperature. The first dimension was performed on a Pharmacia LKB Multiphor II system at 7,000 Vh. After electrofocusing, the IPG strips were reduced in equilibration buffer (50 mM Tris- $\mathrm{HCl}$ buffer, $\mathrm{pH} 6.8,6 \mathrm{M}$ urea, $1 \%(\mathrm{w} / \mathrm{v})$ sodium dodecyl sulfate (SDS), 30\% (v/v) glycerol) containing $1 \%(\mathrm{w} / \mathrm{v})$ DTT and were alkylated with equilibration buffer containing $2.5 \%(\mathrm{w} / \mathrm{v})$ IAA. After equilibration, the IPG strips were analyzed in the second-dimension on a SDS polyacrylamide gel (15\% $(\mathrm{w} / \mathrm{v})$ acrylamide resolving gel) performed in a Hoefer system. Coomassie Brilliant Blue R-250 staining was used to visualize the protein bands.

\section{Tryptic in-gel digestion}

The protein spots were cut out from the gel and the coomassie blue removed using $0.1 \mathrm{M} \mathrm{NH}_{4} \mathrm{HCO}_{3}$ in $50 \%$ (v/ v) acetonitrile until the gel pieces were colorless. After drying of the gel pieces by Speed Vacuum, the gels were reduced with buffer solution $\left(0.1 \mathrm{M} \mathrm{NH}_{4} \mathrm{HCO}_{3}, 1 \mathrm{mM}\right.$ Ethylenediaminetetraacetic acid (EDTA) and $10 \mathrm{mM}$ $\mathrm{DTT})$ at $60^{\circ} \mathrm{C}$ for $45 \mathrm{~min}$. The liquid was removed and then the gel slices covered in $100 \mathrm{mM}$ IAA in $0.1 \mathrm{M}$ $\mathrm{NH}_{4} \mathrm{HCO}_{3}$ solution and incubated at room temperature in the dark for 30 minutes. The residual IAA solution was then removed and the gel pieces were washed with $50 \%(\mathrm{v} / \mathrm{v})$ acetonitrile $(\mathrm{ACN})$ in water, and dried in a Speed Vacuum. Next a trypsin solution $(0.05 \mathrm{M}$ Tris- $\mathrm{HCl}$ buffer $\mathrm{pH} 8.5,0.1 \mu \mathrm{g} / \mu \mathrm{L}$ trypsin in $1 \%(\mathrm{v} / \mathrm{v})$ acetic acid, $10 \%(\mathrm{v} / \mathrm{v}) \mathrm{ACN}$ and $1 \mathrm{mM} \mathrm{CaCl}_{2}$,) was added to the gel pieces and incubated at $37^{\circ} \mathrm{C}$ overnight. Thereafter, the solution was collected and the gels were extracted three times with $2 \%(\mathrm{v} / \mathrm{v})$ trifluoroacetic acid, $0.05 \mathrm{M}$ Tris- $\mathrm{HCl}$ buffer $\mathrm{pH} 8.5$ containing $1 \mathrm{mM} \mathrm{CaCl}_{2}$ and $2.5 \%$ (v/v) formic acid in acetonitrile respectively. The solutions were pooled and dried by Speed Vacuum.

\section{Protein identification by tandem mass spectrometry}

The tryptic peptides were analyzed by using LC/MS/MS, a capillary LC system (Waters) coupled to a Q-TOF mass spectrometer (Micromass, Manchester, UK). The database search was performed with ProteinLynx screening. The Mascot http://www.matrixscience.com/search_form_select.html and the Peaks search tools http://www.bioinfor. com:8080/peaksonline/login.jsp were used for samples where proteins were not found by the ProteinLynx screening. Some proteins were interpreted amino acid sequences using the De novo sequencing tool in Masslynx or the Auto De novo sequencing tool in Peaks online 2.0 and then searched by MS BLAST against the NCBI database http://dove.embl-heidelberg.de/Blast2/msblast.html.

\section{Results and Discussion}

\section{Sample extraction and 2-D IEF-SDS-PAGE profile}

The presence of some substances in plant tissues, such as polysaccharides, lipids, lignins, pigments and phenolic compounds, can interfere with the sample preparation for proteomic analysis. To reduce these compounds a phenol extraction followed by methanol/ammonium acetate precipitation was performed in the protein preparation. At the beginning of protein study, the proteins from $C$. comosa rhizomes were run on 2-D IEF-SDSPAGE using a pH 3 - 10 linear IEF strip (Figure 1A). However, the proteomic pattern showed a high intensity of poorly resolved spots in the acidic region and a low intensity of spots in the basic region, which is somewhat similar to the previously reported protein patterns of $C$. longa [33]. Therefore, to improve the protein separation, a narrow range linear IEF strip of $\mathrm{pH}$ 3.9-5.1 was used (Figure 1B). However, even though some proteins in the acidic region were better resolved, it was still difficult to impossible to identify unique spots. To overcome this problem and enrich the low abundance proteins in the basic region, the effective way is to prefractionate sample. There are several techniques for protein prefractionation such as gel chromatography, selective solublization, sub cellular fractionation and isoelectrofocusing (IEF) which is the one of mostly successful due to its highly resolution and compatibility with subsequent 2DE analysis. Recently, microscale solution-phase isoelectric focusing (MicroSol-IEF) [35,36] was developed for protein prefactionation. The commercial device 

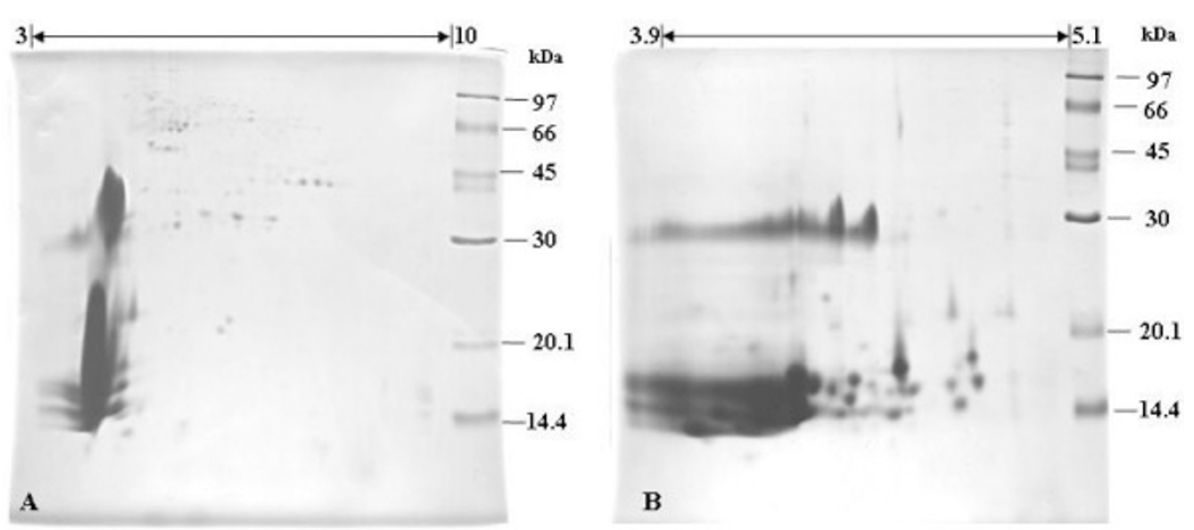

Figure 1 Two-dimensional (IEF-SDS-PAGE) gel electrophoresis profile of the crude phenol-soluble protein fraction isolated from $C$. comosa rhizomes and analyzed using a linear IEF strip of (A) $\mathrm{pH}$ 3-10 and (B) $\mathrm{pH}$ 3.9-5.1. Protein molecular weight markers were cOresolved in the second (SDS-PAGE) dimension on the right hand side, with the sizes indicated in the figure. The gels shown are representative of three such repeats.

based on this approach is known as ZOOM IEF Fractionator (Invitrogen Corp). The protein will be fractionated and trapped in a multichannel of this chamber depends on their $\mathrm{pI}$ values. This technique has been successfully used to separate many types of complexity sample for instance human plasma and serum [37], mouse brain proteins [38] etc. For this reason, we designed to use MicroSol IEF approach to improve protein separation in our study,. The crude proteins were focused in two $\mathrm{pH}$ ranges; the acidic region $(\mathrm{pH} 3-5.4)$ and the basic region ( $\mathrm{pH}$ range 5.4-10). The resolution of the protein patterns obtained following 2-D IEF-SDS-PAGE resolution of these two protein ranges were greatly improved (Figure 2).

\section{Protein Identification}

One hundred and eighty-three spots (70 spots from the acidic region and 113 spots from the basic region) were identified with the aid of the ImageMaster 2D Platinum 7.0 software (GE Healthcare Bio-Sciences). The darkest stained eighty spots in the 2D gel pattern (43 from the acidic region and 37 from the basic region, as shown by numbered circles in Figure 2) were chosen for identification by tryptic in-gel digestion and LC/MS/MS. Unfortunately, thirty-eight $(23(\sim 53 \%)$ from the acidic region and 15 ( $40 \%)$ from the basic region) of these 80 spots could not be identified because of the limitations of existing protein sequences in plant protein database. The putatively identified proteins (Table 1) were grouped according to
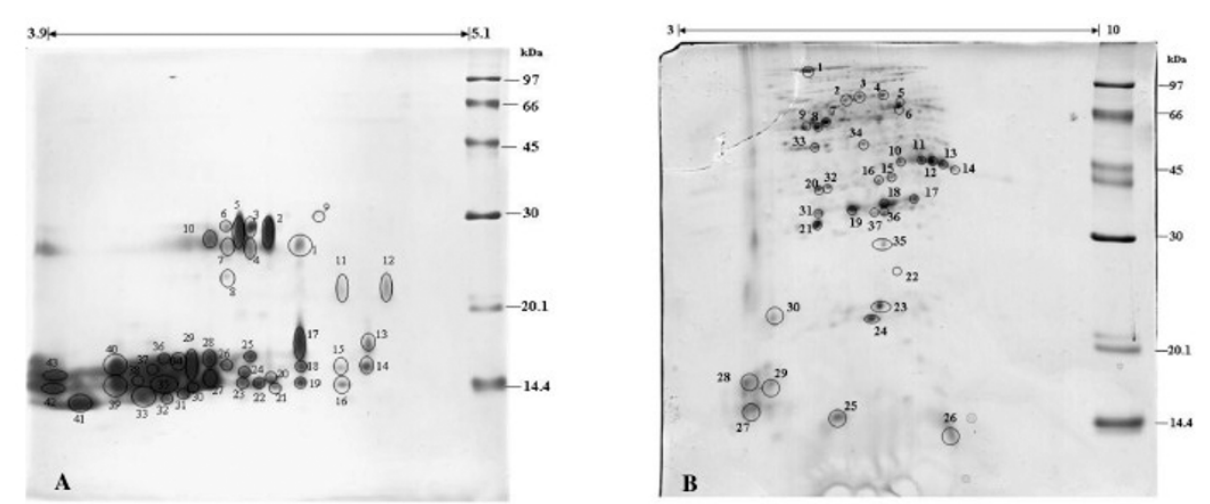

Figure 2 Two-dimensional (IEF-SDS-PAGE) gel electrophoresis profiles of the crude phenol-soluble protein fraction isolated from $C$. comosa rhizomes after separation and enrichment with microscale solution-phase isoelectric focusing (Zoom IEF) at a pH range of (A) 3-5.4 and (B) 5.4-10. The two enriched samples were then resolved in the first dimension using a linear IEF strip of (A) pH 3.9-5.1 and (B) pH 310. Protein molecular weight markers were co-resolved in the second (SDS-PAGE) dimension on the right hand side, with the sizes indicated in the figure. The gels shown are representative of three such repeats. 
Table 1 Phenol-soluble proteins identified from 2-D (IEF-SDS-PAGE) gels of the acidic (pH 3-5.4; spot nos. A2- 40 in figure 2) and basic (pH 5.4-10; spot nos. B4-37 in figure 2) region proteins from C. comosa rhizomes, as analyzed by LC/MS/MS

\begin{tabular}{|c|c|c|c|c|c|c|c|c|}
\hline \multirow[t]{2}{*}{ Spot } & \multirow{2}{*}{$\begin{array}{l}\text { Uniport } \\
\text { ID }\end{array}$} & \multirow[t]{2}{*}{ Protein name } & \multirow[t]{2}{*}{ Organism } & \multirow{2}{*}{$\begin{array}{c}\text { Sequence } \\
\text { coverage (\%) }\end{array}$} & \multirow{2}{*}{$\begin{array}{l}\text { Peptides } \\
\text { matched }\end{array}$} & \multicolumn{2}{|c|}{ Theoretical } & \multirow[t]{2}{*}{ Function } \\
\hline & & & & & & $\begin{array}{l}\mathrm{MW} \\
(\mathrm{Da})\end{array}$ & $\mathrm{pl}$ & \\
\hline$\overline{\mathrm{A} 2}$ & Q40687 & $\begin{array}{l}\text { Guanine nucleotide-binding } \\
\text { protein subunit beta }\end{array}$ & Oryza sativa & 3 & 1 & 41,726 & 7.13 & $\begin{array}{l}\text { Protein } \\
\text { signaling }\end{array}$ \\
\hline A3 & Q9FNA6 & $\begin{array}{l}\text { Genomic DNA, chromosome 5, P1 } \\
\text { clone }\end{array}$ & Arabidopsis thaliana & 6 & 1 & 60,231 & 5.56 & Unknown \\
\hline A5 & P32033 & Protein ycf2 & Cuscuta reflexa & 7 & 1 & 234,393 & 9.25 & ATP binding \\
\hline A8 & O64637 & Cytochrome P450 76C2 & Arabidopsis thaliana & 3 & 2 & 57,221 & 6.50 & Oxidoreductase \\
\hline A7 & Q9MAZ0 & Nonclathrin coat protein & Zea mays & 6 & 1 & 19,928 & 4.81 & $\begin{array}{l}\text { Protein } \\
\text { transport }\end{array}$ \\
\hline A9 & P30182 & DNA topoisomerase 2 & Arabidopsis thaliana & 2 & 2 & 164,005 & 7.25 & ATP binding \\
\hline A11 & Q6ZBQ5 & Hypothetical protein & Oryza sativa & 7 & 1 & 15,105 & 11.6 & Unknown \\
\hline A12 & Q9ZPH2 & Monothiol glutaredoxin-S17 & Arabidopsis thaliana & 3 & 1 & 53,082 & 5.01 & Electron carrier \\
\hline A13 & P27898 & Myb-related protein $\mathrm{P}$ & Zea mays & 2 & 1 & 43,729 & 10.1 & Transcription \\
\hline A16 & A9SACO & Predicted protein & $\begin{array}{l}\text { Physcomitrella patens } \\
\text { subsp patens }\end{array}$ & 4 & 1 & 17,421 & 5.28 & Unknown \\
\hline A17 & Q9LDQ8 & $\begin{array}{l}\text { Similarity to proton pump } \\
\text { interactor }\end{array}$ & Arabidopsis thaliana & 1 & 1 & 58,552 & 5.66 & Unknown \\
\hline A18 & Q2QM00 & $\begin{array}{l}\text { Type IIB DNA topoisomerase family } \\
\text { protein }\end{array}$ & Oryza sativa & 1 & 1 & 55,342 & 5.62 & $\begin{array}{l}\text { DNA/ATP } \\
\text { binding }\end{array}$ \\
\hline A19 & Q9LVP9 & Vesicle transport v-SNARE 13 & Arabidopsis thaliana & 4 & 1 & 25,026 & 9.41 & $\begin{array}{l}\text { Protein } \\
\text { transport }\end{array}$ \\
\hline A20 & Q512R0 & minus agglutinin (SAD1) & Chlamydomonas incerta & 1 & 2 & 404,525 & 6.08 & Defense \\
\hline A25 & Q9GEZ3 & $\mathrm{NADH}$ dehydrogenase subunit $\mathrm{F}$ & Gymnosteris parvula & 2 & 1 & 37,892 & 9.74 & Oxidoreductase \\
\hline A27 & Q6V8L5 & Lectin & Typhonium divaricatum & 12 & 4 & 20,250 & 9.17 & Defense \\
\hline A31 & Q6RHR1 & Basic beta-1,3-glucanase & Capsicum annuum & 6 & 1 & 17,521 & 11.3 & Metabolism \\
\hline A28 & O49565 & Putative F-box protein At4g21240 & Arabidopsis thaliana & 2 & 1 & 48,377 & 5.83 & Unknown \\
\hline A34 & Q41625 & Mannose-binding lectin precursor & Tulipa hybrid cultivar & 13 & 4 & 19,556 & 5.60 & Defense \\
\hline A40 & Q0ZIZ4 & $\begin{array}{l}\text { ATP-dependent Clp protease } \\
\text { proteolytic subunit }\end{array}$ & Vitis vinifera & 5 & 1 & 22,060 & 4.75 & Proteolysis \\
\hline B4 & P93262 & Phosphoglucomutase & $\begin{array}{l}\text { Mesembryanthemum } \\
\text { crystallinum }\end{array}$ & 2 & 1 & 63,446 & 5.87 & Metabolism \\
\hline B5 & Q94C18 & Glycine-rich protein & Solanum lycopersicum & 2 & 1 & 23,420 & 5.88 & Unknown \\
\hline B6 & Q1PCD2 & glucose 6 phosphate isomerase & Solanum lycopersicum & 5 & 2 & 62,739 & 6.56 & Metabolism \\
\hline B7 & Q8LKB0 & enolase & Musa acuminata & 21 & 2 & 15,864 & 7.83 & Metabolism \\
\hline B8 & Q06H19 & UDP glucose pyrophosphorylase & Arachis hypogaea & 22 & 3 & 16,851 & 7.30 & Metabolism \\
\hline B9 & Q859B8 & UGPase PC & Pyrus pyrifolia & 3 & 1 & 50,719 & 5.90 & Metabolism \\
\hline B10 & B2X0E6 & $\begin{array}{l}\text { glyceraldehyde } 3 \text { phosphate } \\
\text { dehydrogenase }\end{array}$ & Mallotus nesophilus & 47 & 2 & 32,795 & 5.96 & Metabolism \\
\hline B11 & Q5PY03 & $\begin{array}{l}\text { glyceraldehyde } 3 \text { phosphate } \\
\text { dehydrogenase }\end{array}$ & Musa acuminata & 2 & 1 & 35,974 & 6.20 & Metabolism \\
\hline B12 & Q2XQF4 & $\begin{array}{l}\text { glyceraldehyde } 3 \text { phosphate } \\
\text { dehydrogenase }\end{array}$ & Elaeis guineensis & 8 & 2 & 32,135 & 7.42 & Metabolism \\
\hline B13 & P34922 & $\begin{array}{l}\text { glyceraldehyde } 3 \text { phosphate } \\
\text { dehydrogenase }\end{array}$ & Pisum sativum & 9 & 3 & 36,586 & 6.63 & Metabolism \\
\hline B14 & A5JEJ7 & $\begin{array}{l}\text { glyceraldehyde } 3 \text { phosphate } \\
\text { dehydrogenase }\end{array}$ & Zehneria keayana & 13 & 1 & 7,001 & 9.87 & Metabolism \\
\hline B15 & P84733 & $\begin{array}{l}\text { Putative cytochrome c oxidase } \\
\text { subunit II PS17 }\end{array}$ & Pinus strobus & 50 & 1 & 33,265 & 7.42 & Unknown \\
\hline B16 & 082450 & $\begin{array}{l}\text { branched chain alpha keto acid } \\
\text { decarboxylase }\end{array}$ & Arabidopsis thaliana & 2 & 1 & 38,709 & 6.27 & Oxidoreductase \\
\hline B17 & Q51LG5 & cysteine protease gp3a & Zingiber officinale & 4 & 4 & 52,062 & 6.17 & Peptidase \\
\hline B18 & Q01H20 & Predicted ATPase (ISS) & Ostreococcus tauri & 1 & 1 & 57,490 & 5.84 & ATP binding \\
\hline
\end{tabular}


Table 1 Phenol-soluble proteins identified from 2-D (IEF-SDS-PAGE) gels of the acidic (pH 3-5.4; spot nos. A2- 40 in figure 2) and basic (pH 5.4-10; spot nos. B4-37 in figure 2) region proteins from C. comosa rhizomes, as analyzed by LC/MS/MS (Continued)

\begin{tabular}{|c|c|c|c|c|c|c|c|c|}
\hline B19 & P25251 & cysteine protease COT44 & Brassica napus & 4 & 1 & 36,277 & 8.05 & Peptidase \\
\hline B21 & Q9FE01 & L-ascorbate peroxidase 2 & Oryza sativa & 15 & 3 & 27,101 & 5.21 & Stress/Defense \\
\hline B23 & Q41561 & Heat shock protein $16.9 \mathrm{C}$ & Triticum aestivum & 16 & 2 & 14,376 & 6.23 & Stress \\
\hline B24 & 022373 & Superoxide dismutase [Cu-Zn] & Capsicum annuum & 10 & 2 & 15,279 & 5.13 & Stress/Defense \\
\hline B33 & Q8LEA2 & Gibberellin 2-beta-dioxygenase 1 & Arabidopsis thaliana & 7 & 2 & 36,709 & 8.53 & Oxidoreductase \\
\hline B34 & Q94A43 & BES1/BZR1 homolog protein 2 & Arabidopsis thaliana & 8 & 1 & 34,174 & 8.63 & Transcription \\
\hline B37 & Q09023 & Endochitinase $\mathrm{CH} 25$ precursor & Brassica napus & 8 & 1 & 34,793 & 6.29 & Metabolism \\
\hline
\end{tabular}

their functions, derived from the annotated function of the homologous protein(s) hits in the database search. Most (jut over one quarter) of the identified proteins were annotated as being involved in metabolic pathways whereas other proteins (in decreasing order of prevalence) were involved in defense/stress response, unknown functions, oxidoreductase/electron carrier, ATP/DNA binding, proteolysis/peptidase, transport/signaling and transcription (Figure 3).

In the acidic region, three mannose-binding lectins with an observed mass range of 14.4 - $17 \mathrm{kDa}$ (spots A20, A27 and A34) were found. Note, however, that the predicted (theoretical) mass of the homologous proteins used to identify these three spots are slightly higher for A27 and A34 (19.5 and $20.3 \mathrm{kDa}$, respectively) but significantly so for A20 with a predicted mass of $404 \mathrm{kDa}$. A mannose binding lectin with a molecular mass of 13.4 $\mathrm{kDa}$ was also isolated from C. zedoary [39]. In addition, six homologous lectin proteins of various molecular masses $(8.84-32.8 \mathrm{kDa})$ were found in C. aromatica [40]. Most of them are mannose binding lectins. With respect to high throughput protein identification, agglutinin was also found to be present in the C. longa 2-D IEF-SDS-
PAGE protein profile [33] at around $14.4 \mathrm{kDa}$ in the acidic region ( $\mathrm{pI} 4.6$ ) which is similar to spot 27 here.

Eleven of the putatively identified proteins from the basic region (Figure $2 \mathrm{~B}$ ) in the $2-\mathrm{D}$ protein pattern were likely to be involved in plant metabolism. Enolase, a ubiquitous enzyme that catalyzes the conversion of 2-phosphoglycerate to phosphoenolpyruvate in the glycolytic pathway, was identified as spot B7. Endochitinase, an enzyme that belongs to the glycosyl hydrolase family and is involved in carbohydrate metabolism and chitin degradation, was present in spot B37. Glyceraldehyde 3 phosphate dehydrogenase, an enzyme that catalyzes the conversion of glyceraldehyde 3 phosphate to D-glycerate 1,3-bisphosphate in the sixth step of glycolysis, was identified as spots B10-14. Four other glycogenesis proteins, phosphoglucomutase, glucose-6-phosphate isomerase, UDP glucose pyrophosphorylase and UGPase, were identified in spots B4, B6, B8 and B9 respectively. Interestingly, two antioxidant proteins were found in the basic region. Superoxide dismutase (SOD), a class of enzymes that convert the reactive superoxide radical into oxygen and hydrogen peroxide, was identified in spot B24. This result is in accord with the recent report

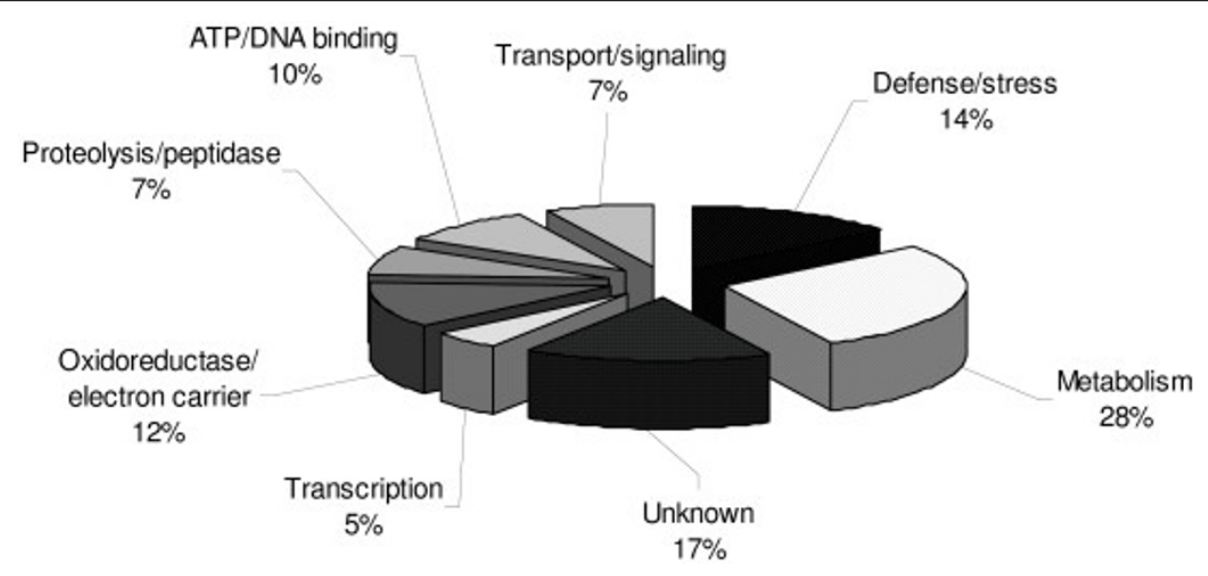

Figure 3 Functional distribution of the 42 putatively identified phenol-soluble proteins (see Table 1) expressed in C. comosa rhizomes. Protein functions are ascribed from that which was annotated in the database to the likely hit (homolog) found by peptide mapping of the tryptic fragments. 
of an antioxidant activity and the isolation of a SOD homologue from C. comosa [41]. Indeed, SOD homologues have also been reported in other Zingiberaceae plant species, such as C. longa [12] and C. zedoaria Roscoe [13]. Their current biotechnological application has mainly been in cosmetic products to reduce free radical levels that otherwise cause skin damage [42]. Ascorbate peroxidase, an enzyme that detoxifies peroxides by using ascorbate as the substrate, was found as spot B21. The main function of this enzyme is control the hydrogen peroxide concentration in cells. The discovery of these two antioxidant enzymes may suggest some benefit for C. comosa for the natural product based cosmetic industry, but this will depend upon their relative specific activity or ease of enrichment. Moreover putative cysteine proteases were identified as spots B17 and B19 at molecular weigh about $20.1 \mathrm{kDa}$ and $14.4 \mathrm{kDa}$ respectively. This enzyme family plays a role in plant growth, development and senescence. Most plant cysteine proteases belong to the papain and legumain families. Recently this enzyme family was reported from three members of the ginger family, in C. longa [43], C. aromatica [40] and Z. offinale Roscoe [44], and this ginger protease is used as a food improver and anti-inflammatory agent. Founding cysteine protease in four members of Zingiberaceae plant, C. comosa, C. longa, C. aromatica and $Z$. offinale at difference molecular weigh and $\mathrm{pI}$ position, the ginger cysteine protease might be a protein marker to classify specific species in this family in the future.

\section{Conclusion}

The protein profile of C. comosa was improved by separation by microscale solution-phase isoelectrofocusing, and identified in part by using high throughput two-dimensional IEF-SDS-PAGE together with tandem mass spectrometry. Some proteins were identified as lectins and antioxidant proteins, which appears to be related with their activity and cysteine proteases that are also found in other Zingiberaceae plant species.

\footnotetext{
Acknowledgements

The authors thank the Thailand Research Fund through the Royal Golden Jubilee Ph.D. Programme (Grant No. PHD/0224/2548), the $90^{\text {th }}$ Anniversary of Chulalongkorn University fund for financial support of this research and Ratchadapisek Somphot Endowment Fund (AG001B), and (AM1019A), the Thai Government Stimulus Package 2 (TKK2555), the National Research University (AS613A) the Department of Chemistry, the Faculty of Science, and the Laboratory of Biochemistry, Chulabhorn Research Institute, are both acknowledged for support and facilities. We also, thank Dr. Robert Butcher (Publication Counseling Unit, Chulalongkorn University) for his constructive comments in preparing this manuscript
}

\section{Author details}

'Department of Chemistry, Faculty of Science, Chulalongkorn University, Bangkok, 10330, Thailand. 'Laboratory of Biochemistry, Chulabhorn Research
Institute, Bangkok, 10210, Thailand. ${ }^{3}$ Research Institute of Biotechnology and Genetic Engineering, Chulalongkorn University, Bangkok, 10330, Thailand.

\section{Authors' contributions}

BA carried out the whole project experiment and drafted the manuscript. SR participated in the design of the study and mass spectroscopy and drafted the manuscript. CD carried out in mass spectroscopy. KA participated in drafted the manuscript and coordination. SP participated in the design of the study and mass spectroscopy and drafted the manuscript. All authors read and approved the final manuscript.

\section{Competing interests}

The authors declare that they have no competing interests.

Received: 7 January 2011 Accepted: 29 July 2011

Published: 29 July 2011

\section{References}

1. Sirirugsa P: Thai Zingiberaceae: Species diversity and their uses. Pure Appl Chem 1998, 70:2111-2118.

2. Shehzad A, Wahid F, Lee YS: Curcumin in Cancer Chemoprevention: Molecular Targets, Pharmacokinetics, Bioavailability, and Clinical Trials. Arch Pharm Chem Life Sci 2010, 1-11.

3. Sun XY, Zheng YP, Lin DH, Zhang H, Zhao F, Yuan CS: Potential anticancer activities of Furanodiene, a Sesquiterpene from Curcuma wenyujin. Am J Chin Med 2009, 37:589-596.

4. Kim M, Miyamoto S, Yasui Y, Oyama T, Murakami A, Tanaka T: Zerumbone, a tropical ginger sesquiterpene, inhibits colon and lung carcinogenesis in mice. Int J Cancer 2009, 124:264-271.

5. Makabe H, Maru N, Kuwabara A, Kamo T, Hirota M: Anti-inflammatory sesquiterpenes from Curcuma zedoaria. Nat Prod Res 2006, 20:680-685.

6. Chopra IC, Jamwal KS, Khajuria BN: Pharmacological action of some common essential oil-bearing plants used in indigenous medicine. I. Pharmacological action of Acorus calamus, Curcuma zedoaria, Xanthoxylum alatum and Angelica archangelica. Indian J Med Res 1954 42:381-384.

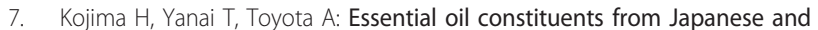
Indian Curcuma aromatica rhizomes. Planta Med 1998, 64:380-381.

8. Lai EY, Chyau CC, Mau JL, Chen CC, Lai YJ, Shih CF, Lin LL: Antimicrobial activity and cytotoxicity of the essential oil of Curcuma zedoaria. Am J Chin Med 2004, 32:281-290.

9. Kundu JK, Na HK, Surh YJ: Ginger-derived phenolic substances with cancer preventive and therapeutic potential. Forum Nutr 2009, 61:182-192.

10. Ghasemzadeh A, Jaafar HZ, Rahmat A: Antioxidant activities, total phenolics and flavonoids content in two varieties of Malaysia young ginger (Zingiber officinale Roscoe). Molecules 2010, 15:4324-4333.

11. Wang H, Ng TB: An antifungal protein from ginger rhizomes. Biochem Biophys Res Commun 2005, 336:100-104

12. Kochhar S, Kochhar VK: Identification and characterization of a superstable Cu-Zn SOD from leaves of turmeric (Curcuma longa L.). Planta 2008, 228:307-318

13. Loc NH, Diem DT, Binh DH, Huong DT, Kim TG, Yang MS: Isolation and characterization of antioxidation enzymes from cells of zedoary (Curcuma zedoaria Roscoe) cultured in a 5-I bioreactor. Mol Biotechnol 2008, 38:81-87.

14. Franco Fraguas L, Carlsson J, Lonnberg M: Lectin affinity chromatography as a tool to differentiate endogenous and recombinant erythropoietins. J Chromatogr A 2008, 1212:82-88.

15. Smetana $\mathrm{K} \mathrm{Jr}$, Andre $\mathrm{S}$ : Mammalian lectin as tool in glycochemistry and histochemistry with relevance for diagnostic procedure. Methods Mol Biol 2008, 418:171-186

16. Smart JD: Lectin-mediated drug delivery in the oral cavity. Adv Drug Deliv Rev 2004, 56:481-489.

17. Rüdiger H, Gabius HJ: Plant lectins: Occurrence, biochemistry, functions and applications. Glycoconjugate J 2001, 18:589-613.

18. Liu B, Bian H, Bao J: Plant lectins: Potential antineoplastic drugs from bench to clinic. Cancer Lett 2010, 287:1-12.

19. Chrispeels MJ, Raikhel NV: Lectins, lectin genes, and their role in plant defense. Plant Cell 1991, 3:1-9. 
20. Damme EJM: Plant Lectins as Part of the Plant Defense System Against Insects. In Induced Plant Resistance to Herbivory. Edited by: Schaller A. Springer Netherlands; 2008:285-307.

21. Chen Z, Kai G, Liu X, Lin J, Sun X, Tang K: cDNA cloning and characterization of a mannose-binding lectin from Zingiber officinale Roscoe (ginger) rhizomes. J Biosci 2005, 30:213-220.

22. Sangvanich P, Kaeothip S, Srisomsap C, Thiptara P, Petsom A, Boonmee A, Svasti J: Hemagglutinating activity of Curcuma plants. Fitoterapia 2007, 78:29-31.

23. Kheeree N, Sangvanich P, Puthong S, Karnchanatat A: Antifungal and antiproliferative activities of lectin from the rhizomes of Curcuma amarissima Roscoe. Appl Biochem Biotechnol 2010, 162:912-925.

24. Konkumnerd W, Karnchanatat A, Sangvanich P: A thermostable lectin from the rhizomes of Kaempferia parviflora. J Sci Food Agric 2010, 90:1920-1925.

25. Christopher JS, Ross CS, Alex S, Aiqun N, Jaswinder SS, Susan RW, Robert CB: Proteomic Classification of Pancreatic Adenocarcinoma Tissue Using Protein Chip Technology. Gastroenterology 2006, 130:1670-1678.

26. Dworzanski JP, Deshpande SV, Chen R, Jabbour RE, Snyder AP, Wick CH, Li L: Mass Spectrometry-Based Proteomics Combined with Bioinformatic Tools for Bacterial Classification. J Proteome Res 2005, 5:76-87.

27. Pepe T, Ceruso M, Carpentieri A, Ventrone I, Amoresano A, Anastasio A: Proteomics analysis for the identification of three species of Thunnus. Vet Res Commun 2010, 34:153-155.

28. Winuthayanon W, Suksen K, Boonchird C, Chuncharunee A, Ponglikitmongkol M, Suksamrarn A, Piyachaturawat P: Estrogenic activity of diarylheptanoids from Curcuma comosa Roxb. Requires metabolic activation. J Agric Food Chem 2009, 57:840-845.

29. Sodsai A, Piyachaturawat P, Sophasan S, Suksamrarn A, Vongsakul M: Suppression by Curcuma comosa Roxb. of pro-inflammatory cytokine secretion in phorbol-12-myristate-13-acetate stimulated human mononuclear cells. Inter Immunopharmacol 2007, 7:524-531.

30. Piyachaturawat $P$, Teeratagolpisal N, Toskulkao C, Suksamrarn A: Hypolipidemic effect of Curcuma comosa in mice. Artery 1997, 22:233-241.

31. Niumsakul S, Hirunsaree A, Wattanapitayakul S, Junsuwanitch N, Prapanupun K: An antioxidative and cytotoxic substance extracted from Curcuma comosa Roxb. J Thai Traditional Medicine 2007, 5:24-29.

32. Jurgens TM, Frazier EG, Schaeffer JM, Jones TE, Zink DL, Borris RP, Nanakorn W, Beck HT, Balick MJ: Novel nematocidal agents from Curcuma comosa. J Nat Prod 1994, 57:230-235.

33. Chokchaichamnankit $D$, Subhasitanont $P$, Paricharttanakul NM, Svasti J, Sangvanich P, Srisomsap C: Proteomic Alterations During Dormant Period of Curcuma Longa Rhizomes. J Proteomics Bioinform 2009, 2:380-387.

34. Bradford MM: A rapid and sensitive method for the quantitation of microgram quantities of protein utilizing the principle of protein-dye binding. Anal Biochem 1976, 72:248-254

35. Zuo X, Speicher DW: Comprehensive analysis of complex proteomes using microscale solution isoelectrofocusing prior to narrow $\mathrm{pH}$ range two-dimensional electrophoresis. Proteomics 2002, 2:58-68.

36. Zuo X, Lee K, Ali-Khan N, Speicher DW: Protein Profiling by Microscale Solution Isoelectrofocusing (MicroSol-IEF). John Wiley \& Sons 2001.

37. Echan LA, Tang HY, Ali-Khan N, Lee K, Speicher DW: Depletion of multiple high-abundance proteins improves protein profiling capacities of human serum and plasma. Proteomics 2005, 5:3292-3303.

38. Myung JK, Lubec G: Use of Solution-IEF-Fractionation Leads to Separation of 2673 Mouse Brain Proteins Including 255 Hydrophobic Structures. J Proteome Res 2006, 5:1267-1275.

39. Tipthara P, Sangvanich P, Macth M, Petsom A: Mannose-binding lectin from Curcuma zedoaria Rosc. J Plant Biol 2007, 50:167-173.

40. Tiptara P, Petsom A, Roengsumran S, Sangvanich P: Hemagglutinating activity and corresponding putative sequence identity from Curcuma aromatica rhizome. J Sci Food Agric 2008, 88:1025-1034.

41. Boonmee A, Srisomsap C, Karnchanatat A, Sangvanich P: An antioxidant protein in Curcuma comosa Roxb. Rhizomes. Food Chem 2011, 124:476-480.

42. Christian Diehl JL, Ledić-Drvar Danijela: The basis of topical superoxide dismutase antipruritic activity. Acta Dermatovenerol Croat 2009, 17:25-39.

43. Nagarathnam R, Rengasamy A, Balasubramanian R: Purification and properties of cysteine protease from rhizomes of Curcuma longa (Linn.). J Sci Food Agric 2010, 90:97-105.
44. Choi KH, Laursen RA: Amino-acid sequence and glycan structures of cysteine proteases with proline specificity from ginger rhizome Zingiber officinale. Eur J Biochem 2000, 267:1516-1526.

doi:10.1186/1477-5956-9-43

Cite this article as: Boonmee et al:: A proteomic analysis of Curcuma comosa Roxb. rhizomes. Proteome Science 2011 9:43.

\section{Submit your next manuscript to BioMed Central and take full advantage of:}

- Convenient online submission

- Thorough peer review

- No space constraints or color figure charges

- Immediate publication on acceptance

- Inclusion in PubMed, CAS, Scopus and Google Scholar

- Research which is freely available for redistribution

Submit your manuscript at www.biomedcentral.com/submit
Biomed Central 